the administration of the purine metabolic analogue, 6-mercaptopurine ${ }^{8}$. This drug also prolongs the survival of skin homografts in rabbits ${ }^{10}$ and renal homotransplants in dogs?.

A more detailed account of our findings, together with further work on the effect of experimental uræmia on classical immunological responses, will be published later.

$$
\begin{aligned}
& \text { G. Gowland* } \\
& \text { F. G. SMIDDY } \\
& \text { R. G. BURWELL } \\
& \text { F. M. Parsons }
\end{aligned}
$$

Departments of Bacteriology,

Surgery, Anatomy and the

Medical Research Council

Unit on Metabolic Disturbances in Surgery, University of Leeds.

* Present address: Department of Zoology, University College, London, W.C.1.

${ }^{1}$ Couch, N. P., et al., J. Clin. Invest., 34, 324 (1957).

- Dammin, G. J., et al., Ann. N.Y. Acad. Sci., 64, 967 (1957).

S Stoloff, J. L., et al., New England J. Med., 259, 320 (1958).

‘ Balch, H. H., Ann. Surg., 142, 145 (1955).

- Medawar, P. B., in Cellular and Bumoral Aspects of the Hypersensitio

- Smiddy, F. G., et al., Brit. J. Surg. (in the press).

"Archibald, R. M., J. Biol. Chem., 157, 507 (1945).

- Schwartz, R., et al., Proc. Soc. Exp. Biol. Med., 99, 164 (1958). J. Clin. Invest. 38, 1394 (1959). Sehwartz, R,, and Dameshek, W., Nature, 188,1602 (1950).

- Meeker, W. R., et al., Proc. Soc. Exp. Biol. Med., 102, 459 (1959); Ann. N. $\dot{Y}$. Acad. Sei., 87, 203 (1960). Robinson, J. L., and Christinn, C. I.; Nature, 187,796 (1960). Schwartz, R., et al., J. Clin. Invest., $\mathbf{3 9}, 952$ (1960).

10 Calne, R. Y., Lancet, 1, 417 (1960).

\section{Demonstration by Paper Electrophoresis of an Auto-immunological Precipitin possibly due to Fibrinolysins}

WE have examined recently blood containing fibrinolysins in high titre. The blood was taken from a man who was later diagnosed as suffering from prostatic malignancy. The presence of high-titre fibrinolysins, raised formal acid phosphatase, and greatly reduced fibrinogen content, were all carried out by routine, accepted biochemical methods, and were fully diagnostic. It was then considered that there could be present a circulating auto-immunological factor which we might be able to demonstrate.

The method chosen was what we have called joint paper electrophoresis, and is essentially that of Flynn and $\mathrm{Mayo}^{1}$, the only addition being that we offer a suitable source of fibrinogen to the serum containing fibrinolysins. We do this by applying plasma from another subject $\mathrm{s}$ short distance behind the serum start line, the result being, naturally, two protein separations, one behind the other. Our findings show that it is possible to produce a thin band typical of auto-immunological precipitins. This band appears in the region of the serum $\gamma$-globulin separation and we believe it to be an auto-immunological fibrinolysate.

Procedures taken to discover the optimal source of fibrinogen and to qualify our belief have been fully embodied in a paper which we hope to publish in the near future.

marion I. Cooper

J. R. SYKeS

Worthing Hospital,

Worthing, Sussex.

- Flynn, F. V., and Mayo, P., Lancet, it, 235 (1951).

\section{PATHOLOGY}

\section{Immunological Observations in Experimental Silicosis}

EVIDENCE which suggests that an immunological mechanism may participate in the pathogenesis of human silicosis has been summarized by Vigliani and Pernis ${ }^{1}$. We have attempted to identify such a mechanism in the experimental disease by applying the fluorescent antibody technique of Coons and Kaplan to rats with silicosis at different stages of development, while observing at the same time the $\gamma$-globulin- and conglutinin-levels in their sera.

Silicosis was induced in rats by the intratracheal injection of a quartz suspension under ether anæesthesia, the rats being killed approximately 1-12 months later. Serum was obtained from the rats by cardiac puncture just before death and analysed for protein composition (paper electrophoresis) and for conglutinin titre ${ }^{2}$. Sera were prepared in rabbits against rat whole-serum and against rat $\gamma$-globulin obtrined by ethanol fractionation ${ }^{3}$. Antibody protein was conjugated with lissamine rhodamine $B 200^{4}$ and applied to sections fixed in ethanol after preparation from freshly frozen silicotic lung in a cryostat. The customary control procedures were employed.

The serum globulin and conglutinin (Table 1) tended to show changes similar in type to those found by Ceppellini and Pernis ${ }^{5}$ in human silicosis. In rats with silicosis more than 6 months the serum globulin was sometimes raised, but there was no elevation in three long survivors. When an increase occurred it mainly affected $\gamma$-globulin, though in some animals there was also a slight elevation of $\beta$-globulin. Silicotic rats often had a considerable augmentation of conglutinating activity in their sera, but this rise was related neither to the duration of their disease nor to the occurrence of hyperglobulinæmia.

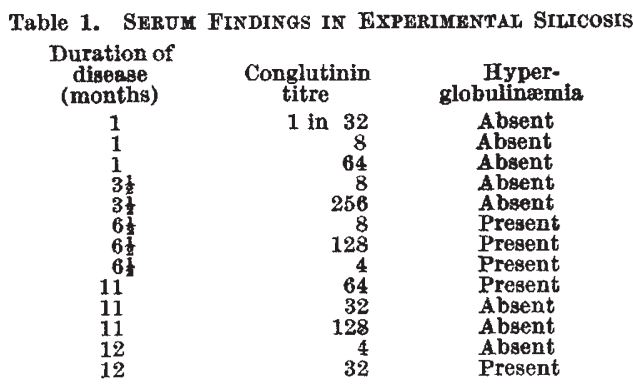

By immuno-electrophoresis ${ }^{6}$, it was established that the rabbit antiserum to rat whole-serum produced precipitin bands to all components of rat serum proteins, whereas the rabbit antiserum to rat $\gamma$-globulin showed the characteristic bands in the appropriate zone with only very slight $\beta$-globulin activity. Although many of the rat silicotic nodules showed hyalinization, no fluorescence of their connective tissue was observed in any of the sections treated with conjugated antibody to rat whole-serum or to rat $\gamma$-globulin. Some fluorescence did, however, occur within the larger blood vessels and in exudate lining alveoli, and was, presumably, a reflexion of the presence of serum proteins. In view of this negative finding in the fibrous tissue of the nodules it was necessary to provide a positive control to our technique. Sections from a human rheumatoid nodule were therefore treated with a conjugated antiserum to human globulin. Vivid specific fluorescence of the 